\title{
Globalization, Poverty and Environmental Degradation: Sustainable Development in Pakistan
}

\author{
Shaista Alam \\ Applied Economics Research Centre, University of Karachi, Karachi 75270, Pakistan \\ Tel: 92-021-9926-1541Ｆax \# 0092-021-9926-1545Ｅ-mail: shaista.alam@aerc.edu.pk
}

\begin{abstract}
The purpose of the present research is to investigate the impact of globalization, and poverty along with other socio-economic and demographic factors (such as industrialization, fertilizer use, urbanization, population growth and education) on environmental degradation in Pakistan. The study analyzed simultaneously the effect of environmental degradation, globalization and poverty on economic growth as well. The Study found a long run relationship between economic growth, environmental degradation, globalization, poverty and other socio-economic and demographic factors mentioned above. The study displayed that increased globalization caused to decrease the rate of environmental degradation and played positive role on economic development in Pakistan. The analysis suggested that poverty may cause to increase environmental degradation and may slower the process of economic development if it is not alleviated. If we want to attain sustainable development in Pakistan, we have to globalize our resources, reduce poverty, own green technologies, control growing population and urbanization rate.
\end{abstract}

Keywords: Sustainable development, Environmental degradation, Biochemical Oxygen demand, Globalization, Poverty, Urbanization, Industrialization, Population growth

The rapid pace of modernization, urbanization, and industrialization has led to serious environmental concerns in the developing countries like Pakistan. Over the past few decades, the natural resources have depleted remarkably resulting from accelerated pace of economic and social transformation. Economic changes such as large increases in population, agricultural output, industrial production, capital accumulation, and innovative technologies have transformed the country's natural resource base, both as a source of factor inputs and as a by product of pollution associated with economic activity. The continuously accelerated and unabated environmental degradation in the country is dangerous for people's health and livelihoods, the survival of species, and ecosystem services that are the foundation for long-term economic development. Economic development and poverty reduction efforts are increasingly constrained by environmental concerns, including degradation of forests and fisheries, lack of fresh water resources, and poor human health as a result of air and water pollution (Banister 1998; Chu and Yu 2002). Intensified crop and livestock production combined with misdirected incentives have contributed to increased production of chemical and organic wastes, natural resource and biodiversity loss, and soil erosion. Lack of an adequate supply of clean water, the explosive growth in population, and the artificial methods of cultivation are the most severe environmental problem in many developing countries, In addition, water quality has been steadily infected by sewage; industrial effluent, urban and agricultural runoff, and saline intrusion. Levels of suspended solids in the rivers increased remarkably high in Pakistan. Biochemical oxygen demand (BOD), a key indicator of overall water quality, is also very high as compare to the level recommended by OECD (Organization for Economic Cooperation and Development).

The relationship between environmental degradation and economic activities becomes the major issue and comes to the focal point of research. The present study tries to find out the linkage between environmental degradation and economic growth and discusses the factors that affecting the environmental degradation and economic growth. In the past decade, many studies have been conducted to test the environmental Kuznut curves (EKCs) hypothesis. EKCs are widely based on the argument that when an economy is at the initial stages of economic growth it may increase pollution along with, once per capita income exceeds a threshold, not only does the structural changes in the economy, but also people can manage to pay for a cleaner environment (Beckerman, 1992; Shafik, 1994; Shafik and Bandyopahay, 1992). The improvement in environmental quality can be achieved by advancing the technological mode of production (de Bruyn, 1997; Xiaoli \& Chatterjee, 1997) or by exporting the "dirty industry" to low income countries (Rock, 1996; Suri \& Chapman, 1998). The empirical research also supports the EKCs along with theoretical models (e.g., Cole, Rayner, \& Bates, 1997; Cropper \& Griffiths, 1994; Grossman \& Krueger, 1993, 1995; Roberts \& Grimes, 1997; Selden \& Song, 1994; Shafik, 1994; Shafik and Bandyopahay, 1992). The basic approach in many empirical studies has nonetheless changed little from the initial study of Grossman and Krueger (1993). This diversity of relationships clearly suggests the need for more elaborated models of the underlying phenomena. Most of the studies deal environmental degradation with the problem of air pollution, while few researchers extend their test of environmental Kuznut curves (EKCs) hypothesis to water pollution. The environmental degradation in terms of water pollution is measured as the rate of growth of emissions of organic water pollutants of Biochemical Oxygen demand (BOD). The poverty and environmental damage are complementary. According to "EKCs" the early stage of development are unavoidably marked by conflicts between poverty reduction and environmental protection (Dasgupta, Deichmann, Meisner, \& Wheeler, 2005).Numerous studies have suggested that environmental damage can have 
particularly significance for the poor, because the poor are least capable of managing the environmental effects (Albla-Betrand 1993; Myers and Kent, 1995).

In the globalization era, countries enhance their interdependence through international trade. For achieving the benefits of globalization, each country needs to faster its growth and economic development through international trade. For this purpose domestic and external environment - economic development and enhancement of trading activities - play an important role in sustainable development of a country and reducing the environmental degradation (Cole 2004). Economic theory suggests that trade between countries with different levels of environmental protection could lead pollution-intensive industry to concentrate in the nations where regulations are lax. Developing countries frequently have less stringent environmental regulations than developed countries. Thus free trade might give developing countries a comparative advantage in industries that are associated with relatively large environmental externalities (Baumol and Oates 1988; Seibert 1981). Evoking this theory, nations that are attractive to industry due to their looser pollution controls are often referred to as "pollution havens."

Cole (2004) argued that trade may reduce pollution due to greater competitive pressure or greater access to greener production technologies. For that reason, the study includes the variable trade openness as a measure of globalization. The variable is defined as the ratio of export plus import to GDP. Managi, Hibiki, \& Tsurumi, (2008) estimated the impact of trade openness on Biochemical Oxygen demand (BOD) emissions for sample of OECD (Organization for Economic Cooperation and Development) countries and non-OECD economies. They found that an increase in trade openness stimulate better water quality, i.e. decreases per capita emissions of BOD. They argued that trade is good for water quality and reduces BOD emissions not only for OECD countries but also for non-OECD economies. Water pollution in the developing nations is caused by animal and human waste, over application of fertilizers, industrial chemicals, urban runoff, and a general lack of pollution prevention laws and their enforcement. Access to adequate wastewater treatment facilities in the developing countries is very limited. As a result, water bodies in the developing nations are often used as open sewers for human waste products and garbage.

The purpose of the present research is to investigate the impact of globalization, and poverty along with other socio-economic and demographic factors (such as industrialization, fertilizer use, urbanization, population growth and education) on environmental degradation in Pakistan. The study will analyze simultaneously the effect of environmental degradation, globalization and poverty (along with all other socio-economic and demographic factors mentioned above) on the economic growth as well. Economic growth is associated with negative externalities, for example environmental degradation, poverty and illetracy, while Economic Development is a an increase in the real income per capita as well as improvements in a variety of indicators such as literacy rates, life expectancy, poverty rates, welfare of the nation, quality of life and quality of environment. Economic development is however concerned with sustainability which means meeting the present needs without compromising future needs. Sustainable development may be defined as continuous increase in the socio-economic standard of living of a country's population, normally accomplished by increasing its stocks of physical and human capital and improving its technology and environment. Jalal (1993) argued that 'Sustainable development can be visualized in terms of a water tank having two leaks, one leak being 'poverty' and the other 'environmental degradation'. Sustainable development will thus remain a dream unless problems of poverty alleviation and control of environmental degradation are dealt with simultaneously". To ensure the sustainable development of the economy environmental degradation should not increase with time but be reduced or at least remain constant. If it increases, the economy will move further away from sustainability, while if it decreases, the economy will move closer towards it.

To best of my knowledge, this is the first systematic quantitative study about the relationship between sustainable development and environmental degradation (in terms of water pollution) with respect to globalization, poverty and other socio-economic variables affecting them, within the Asian region particularly for Pakistan. Alam et al., (2007) estimated the relationship between sustainable development, energy intensity and environmental degradation (in terms of air pollution). Alam et al., (2007) measured the environmental degradation as rate of growth of $\mathrm{CO}_{2}$ emissions. The present study specifies a model in which water pollution (BOD emissions) is associated with globalization, poverty, industrialization, urbanization, fertilizer use, population growth and education. The study further specifies another model in which level of economic development is dependent on globalization, poverty, environmental degradation, industrialization, urbanization, fertilizer use, population growth and education. Remainder of the paper is organized as follows: Section 2 discusses the factors that affect environment as well as development. Section 3 presents theoretical consideration and model specification. Section 4 displays econometric methodology, data sources and variables information, section 5 explains the empirical results and section 6 concludes.

\section{Development and Environment}

The following factors are affecting environment as well as development. 


\section{Globalization}

In general, globalization can affect the environment through trade liberalization by several channels, such as inter-jurisdictional competition to lower standards, transfer of pollution abatement technology, cross-border spillovers, or changes to the overall scale of economies. The various effects of trade on environmental quality can be divided into three components: how trade affects the overall scale of the economy; how trade affects the techniques of production, and how trade affects the composition of industries (Copeland and Taylor, 2003). But the most direct effect of trade liberalization on the environment would be through the composition of industries and hence much of the focus of the literature has been on dissecting the composition effects of trade. Trade liberalization leads to specialization, and countries that specialize in less (more) pollution-intensive goods will have cleaner (dirtier) environments.

This discussion suggests that developing countries may be able to achieve high levels of economic growth and high levels of environmental performance long before they reach the income levels of the industrialized countries. This is not to say that there are no trade off between growth and the environment. Even with good environmental policies and clean technologies, continued increases in output may tend to increase the total volumes of various kinds of pollutants in many cases. Every society has to decide for itself on the relative value it places on economic output and the environment. The point about international openness, though, is that in general it appears to make this tradeoff less painful for developing countries, allowing more environmental protection for the same amount of growth, or more growth for the same amount of environmental protection.

\section{Poverty}

The poor are traditionally taken as the agents for causing society's many problems. The most recent allegation directed against them is that they cause environmental degradation. For example, in one of the conclusions of the Bruntland commission report, which incidentally has been accepted as the proposal for environmental conservation, it is explicitly stated that poverty is a major cause of environmental problems and amelioration of poverty is a necessary and central condition of any effective program to deal with environmental concerns. Jalal (1993), argued that "It is generally accepted that environmental degradation, rapid population growth and stagnant production are closely linked with the fast spread of acute poverty in many countries of Asia". Both poverty and environmental degradation have been increasing in many developing countries. Ethnic minorities, migrants and refugees are the sources of environmental degradation. Their needs often receive far less attention, and they cannot always be reached through the usual hygienic and welfare channels. This problem is increasing in many developing countries, including Pakistan.

Poverty is a major determinant of poor environmental quality as well as a big hurdle to achieving sustainable economic development. Whether defined by income, socioeconomic status, living conditions or educational level, poverty is the single largest determinant of environmental degradation and poor economic growth (Dasgupta et al 2005). Living in poverty is associated with poor sanitary conditions, unabated sewerage system, lack of clean water resources, and increased exposure to environmental risks. Urban poverty is a challenge in all developing countries, where not only the number of urban poor is increasing, but also the divisions among social groups within cities. There is also evidence that rural households use environmental resources quite extensively. The extent of goods and services that environmental resources offer rural households is intensely apparent (Sale 1981). Substantial household use of a range of wild resources has been confirmed by the reviews of Arnold, Liedholm, Mead and Townson (1994), Falconer (1990), Scoones, Pretty and Melnyk (1992) and Townson (1994): these suggest that wild resources may play a very important role in the economy of rural households.

\section{Industrialization}

Economic development in an economy may depend on the fast growing industrialization process. Industrial production generates goods, services and employment which contribute economic growth, but it is also a major source of pollution and waste. Industrialization may speed up process of economic development of a country. According to Neumayer (2003) the industrial sector is usually regarded as more pollution intensive than the services sector. The industrial output might help to explain the level of pollution, because in developing countries, wastewater tends to be dumped into rivers without treatment (WHO/UNEP 1997). The present study includes industrial GDP as an explanatory variable.

\section{Urbanization}

Another major determinant of economic development as well as water pollution is urbanization, the share of urban population in total population. The rate of urbanization and its attendant impacts differ in regions across the globe. Asia contains almost half the world's mega cities and continues to urbanize rapidly. Given its current annual growth rate, Asia's urban population is expected to double in less than 20 years. Urbanizations reflect more than demographic change. It is both driven by and profoundly influences the context and processes of development. It exerts both direct and indirect advantages in the struggle towards global sustainability and human development. The origins of many global environmental problems related to air and water pollution are located in cities (Reddy, 2004). Cole and Neumayer (2004) argued that means of transports, like cars, buses, etc., are more intensively used in urban areas as compared to rural parts of the economy. Moreover food and other 
consumer goods have to be transported into cities, which again should lead to higher pollution. Both examples suggest higher levels of pollution in an economy that is more urbanized.

The other sources of water pollution come from various other different situations which tend to occur in urban areas. For example, soil particles from construction and demolition sites, and also oil and toxic chemicals from car maintenance and runoff from road surfaces (Environmental Agency 2005) are also causes of water pollution. In addition, land in urban cities is covered with 'buildings, asphalt, and concrete', which brings a large amount of quick runoff, contributing to water pollution (Miller 1996: 258; Stapleton et al 2004: 75). Such an urban lifestyle and an urban design are also factors contributing to water pollution. However, much of the sewage in urban areas goes untreated and is dumped into rivers and lakes. As a result, surface water and ground water have been increasingly polluted due to industrial and domestic wastewater and also agricultural runoff (Banister 1998: 995). Furthermore, pollution in urban areas spread to rural areas (Zhang, Vertinsky, Ursacki and Nemetz 1999: 29). Water pollution in urban areas can affect water quality in rural areas. Thus, water pollution in urban cities is one of the serious problems in Pakistan.

\section{Population}

Rapidly increasing population is one of the main obstacles in the way of sustainable economic development and a key determinant of environmental degradation. For example, Kemp (2004: 126, 135) and Chu and Yu (2002: 129) suggest that population growth brings environment deterioration through development, such as large scale farming, urbanization and industrialization. Kempt (2004: 277) also states that population growth and the change of life style and technology brings worse sewage, because the nature cannot keep up with the treatment of the pollution. The Population growth and human activities affect water quality; however, appropriate treatment works can help to avoid the deterioration of water quality. Therefore, it can be said, that whether companies control water pollution produced by them, and whether cities have facilities to treat domestic sewage, are affected by human activities. In developing countries like Pakistan, the facilities of sanitation and hygiene are available to limited urban population. An estimated amount of 17.5 million tons of solid waste is generated every year in Pakistan. Only half is collected and dumped in low-lying land without applying proper sanitary methods. Rest is disposed of at vacant areas, gutters and sewerage system. As far as wastewater management is concerned only few sewerage treatment systems exist. The untreated water flows into Stream Rivers and irrigation canals.

\section{Fertilizer use}

Another human activity that causes water pollution and strengthens economic development is agriculture. The main causes of water pollution from agriculture are pesticides, chemical fertilizers, intensive farming in certain areas, and livestock manure (Environmental Agency 2005; Rogers 2000; WHO/UNEP 1997), which goes into underground water or run off into rivers or surface water (NIAES 2002). This problem is serious in both developed and developing countries, especially in the countries where the population is dramatically increasing; there is a tendency to use enormous amounts of chemical fertilizers, in order to produce enough food for the population (NIAES 2002). These chemical fertilizers contain chemical substances which are harmful to human body if found in sources of drinking water. Cole and Elliott (2003) suggested that higher fertilizer consumption might increase the level of water pollution. Moreover, fertilizer plants are classic "dirty" sector industries. Furthermore, higher fertilizer consumption might increase the agricultural output that can increase the level of economic growth.

\section{Education}

Pollution might also be related to the level of education in a country. Torras and Boyce (1998) as well as Klick (2002) include measures of education as control variables in their respective setup. Hence, higher education may be a prerequisite for a higher demand of a clean environment. Furthermore, education is proxy of human development that play a vital role in economic development. As Solow (1956) showed in the neoclassical growth model that human development is both the result of economic growth and is also an input to it. Thus, human capital acquires profound importance in determining the level of economic growth with respect to education, health and nutrition in the work of Lewis (1955) and then also in modern endogenous growth theories.

\section{Theoretical Considerations and Model Specification}

The study intends to analyze the factors influencing the environmental degradation in terms of water pollution. For this purpose the study need to select an indicator that measures the water pollution. According to European Environmental Agency "BOD is a measure of how much dissolved oxygen is being consumed as microbes break down organic matter. A high demand therefore can indicate that levels of dissolved oxygen are falling with potentially dangerous implications for the river's biodiversity". According to United Nations Environment Programme, "Emissions of organic water pollutants of BOD are measured by biochemical oxygen demand, which refers to the amount of oxygen that bacteria in water will consume in breaking down waste".

Based on the preceding discussion, the theoretical framework for this empirical study is set as follows:

If $\boldsymbol{I N D}$ represents industrial GDP at current factor cost, $\boldsymbol{F R T}$ is fertilizer consumption (in metric tons), $\boldsymbol{U} \boldsymbol{R} \boldsymbol{B} \boldsymbol{N}$ is the rate of urbanization, $\boldsymbol{G L B}$ represents globalization, measured by exports plus imports to GDP ratio, $\boldsymbol{P O P}$ is 
the population growth, $\boldsymbol{P V \boldsymbol { R } T}$ represents poverty, $\boldsymbol{E D U}$ is the education, measured as number of high secondary enrolments and $\boldsymbol{W P}$ is water pollution measured as biochemical oxygen demand, than we can reasonably expect the following relationship:

$$
W P=f(G L B, P V R T, I N D, F R T, U R B N, P O P, E D U)
$$

Expressing the variables in natural logarithms, the base regressions are:

$$
\ln \mathrm{WP}_{\mathrm{t}}=\beta_{0}+\beta_{1} \operatorname{lnGLB}+\beta_{2} \operatorname{lnPVRT}_{\mathrm{t}}+\beta_{3} \ln \mathrm{nND}_{\mathrm{t}}+\beta_{4} \operatorname{lnFRT} \mathrm{T}_{\mathrm{t}}+\beta_{5} \operatorname{lnURBN}_{\mathrm{t}}+\beta_{6} \operatorname{lnPOP}_{\mathrm{t}}+\beta_{7} \operatorname{lnEDU}_{\mathrm{t}}+\varepsilon_{1}
$$

Where, $\beta_{1}$ to $\beta_{7}$ are the elasticities and $\varepsilon_{1}$ is the stochastic error terms with standard properties. In the light of prior discussion, the expected signs of $\beta_{2}, \beta_{3}, \beta_{4}$ and $\beta_{6}$ should be positive and $\beta_{7}$ will be negative. While for rate of urbanization, there exist two alternate views. First view argues that increase in urbanization is the main contributor to environmental pollution. For instance, Panayatou (1993) points out environmental degradation tend to firstly increase as the structure of the economy changes from rural to urban, from agricultural to industrial. But second views suggest that urbanization impact environment positively as urbanization involves more efficient use of infrastructure, more efficient use of transportation and more efficient energy use. So, the coefficient of urbanization $\left(\beta_{5}\right)$ is either negative or positive. Whereas $\beta_{1}$ may be positive or negative, because some critics argue that since increased globalization stimulate higher growth in developing countries; this must lead to more industrial pollution and environmental degradation. Moreover, globalization can provide developing countries with both the incentive to adopt, and the access to, advance technologies, which may provide a cleaner or greener way of producing the good concerned. A World Bank study of steel production in 50 countries found that open economies led closed economies in the adoption of cleaner technologies by wide margins, resulting in the open economies being 17 percent less pollution-intensive in this sector than closed economies (Wheeler, Huq and Martin 1993).

Furthermore, the study extended its empirical analysis to explore the effect of globalization, industrialization, poverty, environmental degradation, population growth, urbanization, fertilizer use and education on economic development. To measure economic development study takes gross domestic product (GDP) per capita at current market price.

$$
G D P=f(G L B, P V R T, I N D, F R T, U R B N, P O P, E D U, W P)
$$

where again taking the natural log of the variables our base regression is:

$$
\begin{aligned}
\ln G D P_{t}=\delta_{0}+\delta_{1} \ln G L B_{t}+\delta_{2} \ln P V R T_{t} & +\delta_{3} \ln I N D_{t}+\delta_{4} \ln F R T_{t}+\delta_{5} \ln U R B N_{t}+\delta_{6} \ln P O P_{t} \\
& +\delta_{7} \ln E D U_{t}+\delta_{8} \ln W P_{t}+\varepsilon_{2}
\end{aligned}
$$

Where $\delta_{1}$ to $\delta_{8}$ are the elasticities and $\varepsilon_{2}$ is the stochastic terms with standard properties.

The study expects $\delta_{l}$ to be positive because globalization is directly associated with higher economic growth. In the light of prior discussion, the expected signs of $\delta_{3}, \delta_{4}$ and $\delta_{7}$ should be positive and $\delta_{2}$ and $\delta_{8}$ will be positive. However, the relationship between water pollution and economic development is complex, because the process of economic development is closely related to growth in industrialization and human activities while this growth in industrialization and human activities is clearly the main cause of increased water pollution. Thus limiting this pollution would affect the process of economic growth. Thus one can reasonably expect positive relation between the two. However, the sign of $\delta_{5}$ could be either positive or negative. The rapid urbanization induced difficulties for the cities in terms of infrastructure shortage, congestion and pollution control. On the other hand, urbanization might be environmental-friendly.

\section{Econometric Methodology}

\section{Unit Root Test}

The distinction between whether the levels or differences of a series is stationary leads to substantially different conclusions and hence test of non-stationarity that is unit roots are the usual practice today. Engle and Granger (1987), define a non-stationary time series to be integrated of order $\mathrm{d}$ if it achieves stationarity after being differentiated $d$. times. This notion is usually denoted by $X_{t} \sim \mathrm{I}(\mathrm{d})$. Hence all the series are tested for the probable order of difference stationarity by using the augmented Dickey-Fuller (ADF) tests. ADF test is a standard unit root test, it analyze order of integration of the data series. These statistics are calculated with a constant and a constant plus a time trend; respectively these tests have a null hypothesis of non-stationarity against an alternative of stationarity. ADF test to check the stationarity of the series is based on the equation of the form:

$$
\Delta \mathrm{Y}_{\mathrm{t}=}=\beta_{1}+\beta_{2} \mathrm{t}+\delta \mathrm{Y}_{\mathrm{t}-1}+\alpha_{\mathrm{i}} \sum^{m} \Delta \mathrm{Y}_{\mathrm{t}-\mathrm{i}}+\varepsilon_{\mathrm{t}}
$$

where $\varepsilon_{\mathrm{t}}$ is a pure white noise error terni $=\mathrm{a}$ and $\Delta \mathrm{Y}_{\mathrm{t}-1}=\left(\mathrm{Y}_{\mathrm{t}-1}-\mathrm{Y}_{\mathrm{t}-2}\right), \Delta \mathrm{Y}_{\mathrm{t}-2}=\left(\mathrm{Y}_{\mathrm{t}-2}-\mathrm{Y}_{\mathrm{t}-3}\right)$ etc.

ADF test determines whether the estimates of $\delta$ are equal to Zero. Fuller (1976) provided the cumulative distribution of the ADF statistics, if the calculated t-ratio of the coefficient $\delta$ is less than the critical value from Fuller table, then $Y_{t}$ is said to be stationary. (Note that' ${ }^{6}$ ' ratio of coefficient $\delta$ is always with a negative sign). Now, consider for example two series $X_{t}$ and $Y_{t}$ both integrated of order (d). Engle and Granger have shown that their linear combination will in general also be $\mathrm{I}(\mathrm{d})$. It is an empirical fact that many important macroeconomic 
variables appear to be integrated of order (d) or I(d) in the terminology of Engle and Granger (1987) so that their changes are stationary. Hence, if the variables are each $\mathrm{I}(\mathrm{d})$ than it may be true that any linear combination of these variables will also be I(d). Having established that all the series are integrated of order (d) that is I(d) the study then proceeds to determine the long run behavioral relationships among the variables for the purpose to examine the long run relationship among the variables.

\section{Testing Co-Integration Using Vector Autoregressive (VAR) Approach}

The VAR model used is denoted as follows:

$$
\mathrm{X}_{t}=\rho_{1} \mathrm{X}_{\mathrm{t} 1}+\rho_{2} \mathrm{X}_{\mathrm{t} 2}+\ldots \ldots \ldots \ldots+\rho_{\mathrm{k}} \mathrm{X}_{t-\mathrm{k}}+t \eta \mu_{\mathrm{t}} \quad 1 \leq \mathrm{t} \leq \mathrm{T}
$$

Where $\mathbf{X}_{\mathrm{t}}$ is a vector containing $W P, G L B, I N D, P V R T, F E R T, U R B N, P O P$ and EDU in the model. Starting from the highest possible lag order, and sequentially testing down to the lowest, the optimal lag order is chosen based on AIC and SBC. After running the VAR model and obtaining the most efficient lag order by observing the AIC and SBC values, long run relationship among the variables have been tested using the Johansen and Juselius (J-J) co-integration technique.

Two or more variables are said to be co-integrated if their linear combination is integrated to any order less than' $d$ '. Co-integration test provides the basis for tracing the long-term relationship. The theory of co-integration put forward by Johansen and Juselius (1990) indicate that the maximum likelihood method is more appropriate in a multivariate system. Therefore this study used this method to identify the number of co-integrated vectors in the model. The selection of " $r$ " co-integrating vector is based on the two statistics defined by Johansen as the maximal eigenvalue and the trace statistic. There is " $\mathrm{r}$ " or more co-integrating vectors. The Johansen model is given by:

$$
\Delta x_{t}=a_{0}+\Pi x_{t-1}+\sum_{i=1}^{k} \theta_{i} \Delta x_{t-k}+\omega_{t} \quad 1 \leq \mathrm{t} \leq \mathrm{T}
$$

Where $\mathbf{X}_{\mathrm{t}}$ is a column vector of $m$ endogenous variables, $\Pi$ and $\theta$ are $m \times m$ matrices of unknown parameters and $\omega_{t}$ is a Gaussian error term. $\Pi$. can be dichotomized into two $m \times r$ matrices Qand $\sigma$. The reduced rank $r<m$ of $\Pi$ is hypothesized as $\mathrm{H}(\mathrm{r}): \Pi=-\Omega \sigma^{\mathrm{T}}$. The vectors of $\sigma$ representing the $\mathrm{r}$ linear combinations of $\sigma^{\mathrm{T}}$ $\mathbf{X}_{\mathrm{t}}$ are stationary. The matrix $\Omega$ represents the error-correction parameters. To investigate the relationship, two main likelihood ratio tests, also known as the trace test to evaluate the null hypothesis of at most $r$ co-integrating vectors and the maximum eigenvalue test, used to evaluate the null hypothesis of $r$ co-integrating vectors against the alternative of $(r+1)$ co-integrating vectors, are used.

\section{Variance Decomposition}

Variance Decomposition separates the variation in an endogenous variable into the component shocks to the VAR. Thus, the variance decomposition provides information about the relative importance of each random innovation in affecting the variables in the VAR. The source of this forecast error is the variation in the current and future values of the innovations to each endogenous variable in the VAR. The remaining columns give the percentage of the forecast variance due to each innovation, with each row adding up to 100 . The variance decomposition based on the Cholesky factor can change dramatically if you alter the ordering of the variables in the VAR.

The VECM, $F$ - and $t$-tests may be interpreted as within-sample causality tests. They can indicate only the Granger exogeneity or endogeneity of the dependent variable within the sample period. They do not provide an indicator of the dynamic properties of the system, nor do they allow us to gauge the relative strength of the Granger-causal chain or degree of exogeneity among the variables beyond the sample period. VDCs that may be termed as out-of-sample causality tests, by partitioning the variance of the forecast error of a certain variable into proportions attributable to innovations (or shocks) in each variable in the system including its own, can provide an indication of these relativities. A variable that is optimally forecast from its won lagged values will have all its forecast error variance accounted for by its own disturbances (Sims, 1982).

\section{Data and Variables Information}

The study is based on annual data covering a time period from 1971 to 2008 for Pakistan. All the time series data of Water Pollution (Organic water pollutant emissions are measured in terms of biochemical oxygen demand -BOD in kilogram per day, which refers to the amount of oxygen that bacteria in water will consume in breaking down waste), gross domestic product (GDP) per capita, industrial GDP in factor cost, total population and the urbanization (percentage of urban population from total population), trade openness, fertilizer consumption (in metric tons) are compiled from World Development Indicators (WDI 2009). (Note 1) The series of Gini Coefficient, the indicator of poverty is taken from Haroon (2006). The series of high school enrolment is taken from Pakistan Economic Survey (Govt. of Pakistan 2009). All these variables are expressed in natural logarithm. 


\section{Empirical Analysis}

\section{Testing of the Unit Root Hypothesis}

A prerequisite in applying the co integration procedure is to test the unit root properties of the data; Table 1 presents statistics describing these properties of the data. For this purpose the present study tested for the existence of a unit root in the level and the first difference of each of the variable under consideration using the well-known Augmented Dickey- Fuller test (ADF test). The summary table of ADF reveals that all variables are non-stationary until being differentiated with the first order.

\section{Multi-variate Co-integration Tests}

After establishment of order of integration for all individual series under consideration, VAR model is used to estimate the co-integrating vectors among the variables. First, the present study estimates model (1) to investigate the impact of globalization, poverty and other socio-economic factors on environmental degradation. For the determination of lag length two VAR versions are initially run: 11 and 12 lag version. Then Akaike information criterion (AIC) and Schwarz Bayesian criterion (SBC) are used to specify the lags. Results suggest that VAR at lag 11 is more appropriate. To establish whether there is a long run relationship among the variables Johansen maximum likelihood approach is conducted. The results from the test are summarized in Table 2, where both the maximal-eigenvalue and trace statistics are used to examine the null hypothesis of no co-integration against the alternative of co-integration. Both trace and max statistics clearly rejects the null hypothesis of no co-integration at 5\% level of significance in favor of the general alternatives of eight and six co-integrating relationships respectively. Therefore, based on the two tests, our annual data from 1971 to 2008 appears to support the proposition that in Pakistan there exist a long run relationship among water pollution $(L W P)$, industrialization (LIND), globalization ( $L G L B)$, poverty (LPVRT), fertilizer consumption (LFRT), education ( $L E D U)$, population ( $L P O P)$ and urbanization ( $L U R B N)$.

Next, study move towards the results of co-integrating coefficients normalized on water pollution. The co-integrating coefficients normalized on water pollution (see table 4 column $2 \& 3$ ) show that $1 \%$ increase in industrialization leads to $0.38 \%$ increase in water pollution. For globalization the coefficient shows that an increase of $1 \%$ in the globalization causes almost $0.05 \%$ decreases in water pollution. The elasticities of fertilizer consumption and urbanization are found to be affecting the level of water pollution significantly and positively by $0.2 \%$ and $0.1 \%$ respectively. This indicates that in Pakistan fertilizer use and urbanization growth adversely affect environment. The result further shows that increase in population do not effect environment significantly but its sign is positive, which implies that population may caused to increase environmental degradation. As number of high school enrolment increases $1 \%$, water pollution decreases by $0.08 \%$. This result implies that education generates the awareness in the people to protect environment. The coefficient of poverty is not statistically significant at 10 percent level, but it is near to significance level, which implies that poverty may cause to increase environmental degradation in near future if it would not be alleviated.

As far as economic development model concern, there is only one VAR version runs for lag length 11 , because sample size does not allow the higher lag version of VAR to be estimated. The maximum likelihood ratio test (trace statistics) and maximum eigenvalue statistics are used to identify the presence of common stochastic trends. The results from these tests conducted are presented in Table 3, where both the max and trace statistics are used to examine the null hypothesis of no co-integration against the alternative of co-integration. Both trace and max statistics clearly reject the null hypothesis of no co-integration at $5 \%$ level of significance in favor of the general alternatives of six co-integrating relationships exist for each test. Therefore, based on the two tests, results provide the evidence to support the hypothesis that there exist a long run relationship among economic development $(L G D P)$, water pollution $(L W P)$, industrialization $(L I N D)$, globalization $(L G L B)$, poverty $(L P V R T)$, fertilizer consumption (LFRT), education (LEDU), population (LPOP) and urbanization (LURBN).

The co-integrating coefficients normalized on economic development (LGDP) displayed in table 4, column 4 \& 5. The normalized co-integration coefficients indicate that 1 percent increase in globalization will increase economic development by 0.17 percent, 1 percent increase in industrial output will increase economic development by 0.35 percent and 1 percent increase in fertilizer use will increase economic development by 0.5 percent, while 1 percent increase in population growth will decrease economic growth by 0.08 percent in Pakistan in the long run. The results suggest that globalization, industrialization and fertilizer use have played positive and significant role on economic development, whereas increase in population growth has slowdown the process of economic development in Pakistan. The normalized coefficient for education and water pollution are positive but insignificant, suggesting that education and water pollution may faster the speed of economic development. However, increase in water pollution is harmful, but in the consequence of increase in agricultural and industrial output, water pollution may indirectly cause to speed up economic development. The coefficient of poverty and urbanization are negative but insignificant, implies to suggest that increase in poverty and rapid urbanization may slower the process of economic development in Pakistan. 


\section{Variance Decomposition}

After establishing the long-run relationship between the variables under consideration, the variance decomposition technique is performed that can provide an indication of variation in target variable explained by policy variables in future. It focuses on forecast error variance (FEV) into the components accounted for by innovations in the individual variables; this analysis is provided in Table 5 and 6 . The VDCs could be deemed to be an exercise of an out-of-sample causality test, whereas the VECM F-test tells us within-sample effects of "anticipated" (say policy) variable on target variables (present study did not perform VECM because the environmental degradation is a long-run phenomenon and have long run impact on economic growth). The VDCs tell us the relative strength of the variables and also the out-of-sample "unanticipated" impact of a policy variable on a target variable. In the dynamic interactions between water pollution and its determinants, the role of water pollution stands out clearly in relation to that of socioeconomic variables.

As presented in Table 5, although most of the variation in water pollution is explained by its own shock, a very little portion of the variance of water pollution is explained by shocks in industrialization, globalization, agriculture activity (fertilizer use), urbanization and population (less than $1 \%$ each), while $27 \%$ and $3 \%$ variance of water pollution is explained by shocks in education and poverty respectively in the short run (at 2-year horizon). In the long run at 10 year horizon significant portion of variation in water pollution is explained by all the variables except population, such as $14.3 \%$ by industrialization, $13.5 \%$ by education, $12.4 \%$ by agriculture activity, $10.4 \%$ by poverty, $7.6 \%$ by globalization and $7 \%$ by urbanization. At 15 to 20 year horizon most of the variation in water pollution is explained only due to shocks in industrialization and agriculture activity, where as some portion of variation in water pollution is due to shocks in urbanization, globalization and poverty. The results of variance decomposition conclude that variation in water pollution is explained in the short run due to shocks in education and in the long run due to agriculture activity (fertilizer consumption) and industrialization.

Table 6 displayed the forecast variance of economic development. Contribution in the variation of economic development explained by shocks in population growth is $13 \%$, agricultural activity is $7 \%$ and urbanization is $4 \%$, where as very little portion of variation explained by industrialization, poverty, education and globalization in the short run (at 2 year horizon). However in the long run, maximum contribution of variation in economic development is explained by water pollution and it followed by agricultural activity, industrialization and globalization. The results suggest that variation in economic development explained in the short run due to the shocks in population growth and in the long run due to shocks in agricultural and industrial activities and globalization.

\section{Concluding Remarks}

The present study investigated the long run relationship between globalization, poverty and environmental degradation along with other socio-economic and demographic factors, such that education, industrialization and agriculture output, urbanization and population in case of Pakistan. The Study simultaneously found a long run relationship between economic growth, environmental degradation, globalization, poverty and other socio-economic and demographic factors mentioned above. The study demonstrated that expansion in intensive industrial and agricultural activities and rapid urbanization affect environment adversely, while increased globalization has caused to decrease the rate of environmental degradation. The evidence also suggests that industrial and agricultural output and globalization played positive effect on economic development, whereas rapidly growing population is a big hurdle to achieve economic development in Pakistan. The analysis suggested that poverty may cause to increase environmental degradation and it may slow down the process of economic development if it would not be alleviated. The education which is the indicator of human development generates the awareness in people to protect environment and it further improves the economic development of a country. The results further suggest that the effect of education is significant to reduce the environmental degradation; while it can play a positive role to attain sustainable development in Pakistan. As far as, the effect of water pollution on economic development concerned, it does not significantly affect economic development adversely. If we want to sustain our development, then we have to control water pollution and protect our environment. If we want to attain sustainable development in Pakistan, we have to globalize our resources, increase the serious efforts of poverty reduction, own green and clean technologies to increase industrial and agriculture output, control the growing population and urbanization rate.

According to Jalal (1993), "two leaks of sustainable development, i.e., poverty and environmental degradation", the present study found that two leaks are not significantly affecting sustainable development in Pakistan but their signs represent an alarming situation that poverty and environmental degradation may adversely affect sustainable development unless problem of poverty alleviation and control of environmental degradation are dealt with simultaneously in case of Pakistan. As far as globalization is concerned it can play positive and significant role in attaining sustainable development by protecting environment through adaptation of green technologies. Last but not least, there is need to enhance the level of education in Pakistan that can help to alleviate poverty, increase the awareness of environmental protection and generate the understanding to globalize resources. 


\section{References}

Alam, S., Fatima A., and Butt M. S. (2007). Sustainable Development in Pakistan in the Context of Energy Consumption Demand and Environmental Degradation. Journal of Asian Economics, 18, 825-837.

Albla-Betrand, J. M. (1993). The political economy of large natural disasters. Oxford: Clarendon Press.

Arnold, J. E. M., Liedholm, C., Mead, D., \& Townson, I. M. (1994). Structure and growth of small scale enterprises in the forest sector in southern and eastern Africa. OFI Occasional Paper No. 47. Oxford Forestry Institute, University of Oxford, Oxford.

Banister, J., (1998). Population, Public Health and the Environment in China. The China Quarterly, 156, Special Issue: China's Environment, 986-1015.

Baumol, W. and Oates, W. (1988). The Theory of Environmental Policy. Cambridge University Press, New York.

Beckerman, W. 1992. Economic Growth and the Environment: Whose Growth? Whose Environment? World Development 20: $481-496$.

Chu, C. Y. C., and Yu, R. -R., (2002). Population Dynamics and the Decline in Biodiversity: A Survey of the Literature, in Population and Environment: Methods of Analysis, Luts, W., Prskawetz, A., and Sanderson, W. C., (eds.), Population and Development Review, Population Council: New York.

Cole, M. A. (2004). Trade, the pollution haven hypothesis and the environmental Kuznets curve: Examining the linkages. Ecological Economics, 48, 71-81.

Cole, M. A. and Elliott, R. J. R. (2003). Determining the trade-environment composition effect: The role of capital, labor and environmental regulations. Journal of Environmental Economics and Management, 46, 363-383.

Cole, M. A., \& Neumayer, E. (2004). Examining the impact of demographic factors on air pollution. Population and Development Review, 26(1), 5-21.

Cole, M. A., Rayner, A. J. and Bates, J. M., 1997. The environmental Kuznets curve: an empirical analysis. Environment and Development Economics, 2: 401-416.

Copeland, B.R., and M.S. Taylor (2003). North-South Trade and the Environment. Quarterly Journal of Economics August, 755-87.

Cropper. M and C. Griffiths, (1994). The interaction of population growth and environmental quality, American Economic Review 82 (1994), pp. 250-254.

Dasgupta, S., Deichmann, U., Meisner, C., \& Wheeler, D. (2005). Where is the poverty-Environment nexus? Evidence from Cambodia, Lao PDR, and Vietnam. World Development, 33(4), 617-638.

de Bruyn, S. M. (1997). Explaining the environmental Kuznets curve: structural change and international agreements in reducing sulphur emissions. Environment and Development Economics, 2: 485-503.

Grossman G., Krueger A.B. (1993) Environmental impacts of a North American free trade agreement. In:Garber P., (Eds). The US-Mexico Free Trade Agreement. MIT Press, Cambridge.

Grossman G., Krueger A.B. (1995) Economic growth and the environment Quarterly Journal of Economics 112:353-377.

Engle, R. F., \& Granger, C. W. J. (1987). Co-integration and error correction: Representation, estimation and testing. Econometrica, 55, 251-276.

Environment Agency, (2005). Impacts of proposed housing growth in south and east England: water resources and water quality. Part of Environmental impacts of housing growth in the south and east of England (SCHO0806BLFD-E-C). Available from publications catalogue at www.environment-agency.gov.

Falconer, J. (1990). The major significance of minor forest products: the local use and value of forests in the West African humid forest zone. Forests, Trees and People, Community Forestry note No. 6. FAO, Rome.

GOP (2009), Pakistan Economic Survey, Ministry of Finance, Government of Pakistan.

Haroon Jamal. (2006). Does Inequality Matter for Poverty Reduction? Evidence from Pakistan's Poverty Trends. The Pakistan Development Review, 45(3), 439-459.

Huq, M., and D. Wheeler, (1993). Pollution Reduction without Formal Regulation: Evidence from Bangladesh. World Bank, Environment Department Working Paper.

Jalal, K.F. (1993). Sustainable development, environment and poverty nexus, In: Occasional papers No. 7, Asian Development Bank, Manila.

Johanson, S., \& Juselies, K. (1990). Maximum likelihood estimation and inference on co-integration with applications for the demand for money. Oxford Bulletin of Economic and Statistics, 52, 169-210. 
Kemp, D. D. (2004). Exploring Environmental issues: An Integrated Approach, Routledge: London and New York.

Klick, J. (2002). Autocrats and the environment or it's easy being green. Working Paper Series 02-16, George Mason University.

Lewis, W. Arthur. (1955). The Theory of Economic Growth, London: Allen \& Unwin.

Lipset, S. M. (1959). Some social requisites of democracy: Economic development and political legitimacy. American Political Science Review, 53, 69-105.

Managi Shunsuke \& Hibiki Akira \& Tsurumi Tetsuya. (2008). Does Trade Liberalization Reduce Pollution Emissions? Discussion papers 08013, Research Institute of Economy, Trade and Industry (RIETI).

Miller, G. T. (1996). Living in the Environment: Principles, Connections, and Solutions, Wodsworth: Melbourne.

Myers, N., \& Kent, J. (1995). Environmental exodus-An emergent crisis in the global arena. Washington, DC: Climate Institute.

Neumayer, E. (2003). Are left-wing party strength and corporatism good for the environment? Evidence from panel analysis of air pollution in OECD countries. Ecological Economics, 45, 203-220.

NIAES (2002). Annual Report of National Institute for Agro-Environmental Sciences Japan, (April 2001 March 2002).

Panayatou, T. (1993). Empirical tests and policy analysis of environmental degradation at different stages of economic development (p. 42) (World Employment Research ProgrammeWorking Paper). Geneva: International Labour Office.

Reddy, A. K. N. (2004). Energy and Social Issue. In T. B. Johansson \& J. Goldemberg (Eds.), Energy and the challenge of sustainability. New York: UNDP, UNDESA and WEC.

Roberts J.T., Grimes P.E. (1997) Carbon intensity and economic development 1962-91: a brief exploration of the Environmental Kuznets Curve World Development 25:191-198.

Rock, M.T. (1996). Pollution intensity of GDP and trade policy: can the World Bank be wrong. World Development 24, pp. 471-479.

Rogers V. (2000). 'Agriculture, Water Pollution and the Regional Dimension in French Public Policy', Journal of European Area Studies, 8 (1), 35-56.

Sale, J. B. (1981). The importance and values of wild plants and animals in Africa. Gland, Switzerland: IUCN.

Selden T.M., Song D. (1994). Environmental quality and development: is there a Kuznets Curve for air pollution emissions Journal of Environmental Economics and Management 27:147-162

Scoones, I., Pretty, J. N., \& Melnyk, M. (1992). The hidden harvest: wild foods in agricultural systems. A bibliography and literature review. London: International Institute for Environment and Development.

Seibert, H. (1981). International Dimension. Economics of Environment, 131-142.

Shafik N. (1994) Economic development and environmental quality: an econometric analysis Oxford Economic Papers 46:757-773.

Shafik N., Bandyopadhyay S. (1992). Economic Growth and Environmental Quality. Background Paper for the 1992 World Development Report, The World Bank, Washington D.C.

Solow, Robert M. (1956). A Contribution to the Theory of Economic Growth. Quarterly Journal of Economics, 70, 65-94.

Suri V., Chapman D. (1998) Economic growth, trade, and energy: implications for the Environmental Kuznets Curve Ecological Economics 25:195-208

Stapleton, R. M., Hemminger, P., and Senecah, S. L. (2004). Pollution A to Z Vol.2, Macmillan Reference USA: New York.

Torras, M. and Boyce, J. K. (1998). Income, inequality, and pollution: A reassessment of the environmental Kuznets curve. Ecological Economics, 25, 147-160.

Townson, I. M. (1994). Forest products and household incomes: a review and annotated bibliography. Mimeo. Oxford: Forestry Institute, University of Oxford.

XIAOLI, H. and CHATTERJEE, L. (1997). Impacts of growth and structural change on $\mathrm{CO}_{2}$ emissions of developing countries. World Development, 25(3): 395-407.

WHO/UNEP, (1997). Water Pollution Control - A Guide to the Use of Water Quality Management Principles. http://www.who.int/docstore/water_sanitation_health/wpcontrol/begin.htm

World Bank. (2009). World Development Indicators (WDI) 2009 CD-ROM. Washington: The World Bank. 
Zhang, W., Vertinsky, I., Ursacki, T., and Nemetz, P. (1999). Can China Be A Clean Tiger? Growth Strategies and Environmental Realities. Pacific Affairs, 72(1), 23-37.

Notes:

Note 1. Data taken from WDI. (2009) is up to 2007 which was updated till 2008 by using the growth rate.

Table 1. ADF Unit Root Test

\begin{tabular}{|c|c|c|c|c|}
\hline \multirow[b]{2}{*}{ Variables } & \multicolumn{2}{|c|}{ Level } & \multicolumn{2}{|c|}{ First Difference } \\
\hline & Constant & Const. \& Trend & Constant & Const. \& Trend \\
\hline LWP & -2.45 & -2.59 & $-8.55^{*}$ & $-9.17^{*}$ \\
\hline LIND & -0.82 & 2.57 & $-5.94 *$ & $-6.16^{*}$ \\
\hline LGLB & -2.02 & -2.00 & $-4.43^{*}$ & $-4.35^{*}$ \\
\hline LFRT & -2.19 & -1.55 & $-5.38^{*}$ & $-6.47 *$ \\
\hline LPVRT & -2.47 & -2.80 & $-3.43 * *$ & $-4.84 *$ \\
\hline LEDU & -0.99 & -0.73 & $-3.76^{*}$ & $-3.76 * *$ \\
\hline LURBN & -1.78 & -2.63 & $-3.49 * *$ & $-3.87 *$ \\
\hline LPOP & -1.49 & -2.99 & $-2.78 * * *$ & $4.82 *$ \\
\hline
\end{tabular}

Table 2. Johansen Maximum Likelihood Co-Integration Test

(Dependent Variable: LWP)

\begin{tabular}{|c|c|c|}
\hline $\begin{array}{c}\text { Hypothesized No. of Cointegrating } \\
\text { Equations }\end{array}$ & $\begin{array}{c}\text { Trace } \\
\text { Statistic }\end{array}$ & $\begin{array}{c}\text { Max-Eigenvalue } \\
\text { Statistic }\end{array}$ \\
\hline None & $377.6098^{*}$ & $119.0635^{*}$ \\
\hline At most 1 & $258.5463^{*}$ & $83.7830^{*}$ \\
\hline At most 2 & $174.7632^{*}$ & $48.7763^{*}$ \\
\hline At most 3 & $125.9868^{*}$ & $47.1067^{*}$ \\
\hline At most 4 & $78.8801^{*}$ & $32.5633^{*}$ \\
\hline At most 5 & $46.3167^{*}$ & $27.4527^{*}$ \\
\hline At most 6 & $18.8640^{*}$ & $6.7392^{*}$ \\
\hline At most 7 & $6.7392^{*}$ & \\
\hline $\begin{array}{l}\text { Trace test indicates 8 cointegrating equation(s) at the } 0.05 \text { level. } \\
\text { Max-eigenvalue test indicates 6 cointegrating equation(s) at the } 0.05 \text { level. } \\
* \text { denotes rejection of the hypothesis at the 0.05 level. }\end{array}$ \\
\hline
\end{tabular}

Table 3. Johansen Maximum Likelihood Co-Integration Test

(Dependent Variable: LGDP)

\begin{tabular}{|c|c|c|}
\hline $\begin{array}{c}\text { Hypothesized No. of Cointegrating } \\
\text { Equations }\end{array}$ & $\begin{array}{c}\text { Trace } \\
\text { Statistic }\end{array}$ & $\begin{array}{c}\text { Max-Eigenvalue } \\
\text { Statistic }\end{array}$ \\
\hline None & $454.1137^{*}$ & $128.4752^{*}$ \\
\hline At most 1 & $325.6385^{*}$ & $108.2984^{*}$ \\
\hline At most 2 & $217.3401^{*}$ & $80.8961^{*}$ \\
\hline At most 3 & $136.4439^{*}$ & $35.2382^{*}$ \\
\hline At most 4 & $91.20571^{*}$ & $29.7945^{*}$ \\
\hline At most 5 & $53.18754^{*}$ & 11.3218 \\
\hline At most 6 & 23.3929 & 8.2598 \\
\hline At most 7 & 12.0711 & 3.8112 \\
\hline At most 8 & 3.8112 & \\
\hline $\begin{array}{l}\text { Trace test indicates 6 cointegrating equation(s) at the } 0.05 \text { level. } \\
\text { Max-eigenvalue test indicates 6 cointegrating equation(s) at the } 0.05 \text { level. } \\
\text { * denotes rejection of the hypothesis at the 0.05 level. }\end{array}$ \\
\hline
\end{tabular}


Table 4. Normalized co-integrating coefficients

\begin{tabular}{|c|c|c|c|c|}
\hline $\begin{array}{c}\text { Independent } \\
\text { variables }\end{array}$ & \multicolumn{2}{|c|}{$\begin{array}{c}\text { Normalized co-integrating coefficients on } \\
\text { LWP }\end{array}$} & \multicolumn{2}{c|}{ Normalized co-integrating coefficients on } \\
\hline & Coefficients & t-statistics & $0.1708^{* *}$ & 2.1933 \\
\hline LGLB & $-0.0495^{* * *}$ & -1.8546 & -0.2954 & -0.8976 \\
\hline LPVRT & 0.0630 & 1.6001 & $0.3538^{*}$ & 2.8671 \\
\hline LIND & $0.3796^{* *}$ & 2.1131 & $0.4903 * * *$ & 1.8866 \\
\hline LFRT & $0.2034^{*}$ & 3.3778 & -0.2147 & -0.6567 \\
\hline LURBN & $0.1060^{* *}$ & 2.1565 & $-0.0828 * *$ & -2.0269 \\
\hline LPOP & 0.1272 & 0.2478 & 0.0914 & 0.4916 \\
\hline LEDU & $-0.0845^{* * *}$ & -1.8078 & 0.1705 & 0.5276 \\
\hline LWP & -- & - & \\
\hline
\end{tabular}

Table 5. Decomposition of Variance (percentage of Forecast variance explained by innovations)

\begin{tabular}{|c|c|c|c|c|c|c|c|c|}
\hline \multicolumn{10}{|c|}{ Relative Variance of Water Pollution (LWP) } \\
\hline Period & LWP & LIND & LGLB & LFRT & LPVRT & LEDU & LURBN & LPOP \\
\hline 1 & 100.00 & 0.00 & 0.00 & 0.00 & 0.00 & 0.00 & 0.00 & 0.00 \\
\hline 2 & 66.93 & 0.47 & 0.10 & 0.92 & 3.19 & 27.38 & 0.69 & 0.32 \\
\hline 3 & 56.09 & 1.47 & 6.41 & 2.32 & 3.96 & 27.88 & 1.06 & 0.81 \\
\hline 4 & 53.39 & 1.34 & 5.89 & 2.36 & 6.32 & 26.58 & 1.86 & 2.26 \\
\hline 5 & 45.07 & 1.12 & 11.22 & 3.03 & 12.25 & 22.87 & 2.52 & 1.92 \\
\hline 10 & 33.23 & 14.33 & 7.59 & 12.37 & 10.42 & 13.53 & 6.97 & 1.56 \\
\hline 15 & 27.35 & 28.01 & 3.97 & 24.05 & 5.30 & 3.06 & 7.12 & 1.15 \\
\hline 20 & 26.48 & 29.23 & 4.56 & 25.23 & 4.93 & 2.24 & 6.31 & 1.02 \\
\hline
\end{tabular}

Table 6. Decomposition of Variance (percentage of Forecast variance explained by innovations)

\begin{tabular}{|c|c|c|c|c|c|c|c|c|c|}
\hline \multicolumn{10}{|c|}{ Relative Variance of Economic Growth (LGDP) } \\
\hline Period & LGDP & LIND & LFRT & LEDU & LWP & LPOP & LPVRT & LURBN & LGLB \\
\hline 1 & 100.00 & 0.00 & 0.00 & 0.00 & 0.00 & 0.00 & 0.00 & 0.00 & 0.00 \\
\hline 2 & 69.44 & 2.76 & 6.88 & 1.12 & 0.02 & 13.03 & 1.66 & 4.13 & 0.96 \\
\hline 3 & 26.80 & 18.28 & 5.82 & 4.86 & 11.01 & 9.47 & 0.90 & 22.49 & 0.37 \\
\hline 4 & 15.94 & 22.09 & 5.85 & 9.52 & 21.94 & 5.56 & 1.08 & 15.97 & 2.05 \\
\hline 5 & 9.72 & 19.91 & 14.62 & 4.84 & 33.07 & 2.66 & 2.28 & 8.59 & 4.31 \\
\hline 10 & 7.81 & 11.07 & 20.80 & 2.84 & 45.62 & 0.64 & 0.49 & 2.42 & 8.31 \\
\hline 15 & 6.77 & 10.20 & 20.32 & 2.93 & 47.24 & 0.93 & 0.50 & 1.04 & 10.07 \\
\hline 20 & 1.23 & 7.18 & 9.73 & 18.38 & 4.48 & 46.39 & 1.12 & 0.55 & 10.34 \\
\hline
\end{tabular}

